\title{
Cortisol Profiles in Pregnancy as a Psychobiological Predictor of Gestation Period and Birth Weight ${ }^{1,2}$
}

\author{
永岑 光恵 (東京工業大学) \\ 斉藤＼cjkstart哲（ピジョン株式会社） \\ 岡林 秀樹 (明星大学) \\ 金 吉晴 (国立精神・神経医療研究センター)
}

\section{Cortisol Profiles in Pregnancy as a Psychobiological Predictor of Gestation Period and Birth Weight ${ }^{1,2}$}

\author{
Mitsue Nagamine (Institute for Liberal Arts, Tokyo Institute of Technology) \\ Satoru SAIto (Research \& Development Division, Breastfeeding Laboratory, Pigeon Corporation) \\ Hideki OKabayashi (Department of Psychology, Meisei University) \\ Yoshiharu KIM (National Institute of Mental Health, National Center of Neurology and Psychiatry)
}

\begin{abstract}
Prenatal maternal stress impacts fetal growth that can be assessed using cortisol profiles. However, the association between maternal mental health, cortisol profile, and fetal growth remains unclear. This study assessed the cortisol awakening response (CAR) and diurnal cortisol slope (DCS) as the cortisol profile. Healthy pregnant women ( $N=44,20$ mid-term, 24 late-term; mean age, 29.3 years) participated in this study. Participants' mental health was assessed using the General Health Questionnaire, and saliva samples were collected eight times a day for cortisol assessment. The latent growth curve analysis of diurnal cortisol changes using Hierarchical Linear Modeling showed that the intercept and the negative slope were significant. The effects of these intercepts and slopes on the gestation period and birth weight were examined through multiple regression analyses. The results showed that only DCS had a marginally negative association with infant's birth weight $(\beta=$ $-.52, p<.10$ ), after controlling for confounding factors. The DCS might be a better tool for assessing the mental health status during pregnancy, which could also be a better predictor of the birth weight than CAR.
\end{abstract}

Key words: pregnancy, birth weight, cortisol diurnal rhythm; cortisol awakening response, hypothalamuspituitary-adrenal (HPA) axis

2018.4.28受稿, 2018.9.22 受理, doi: 10.5674/jjppp.1802si

連絡者及び連絡先： 7 152-8550 東京都目黑区大岡山2-12-1, W9-53 東京工業大学 永岑光恵

E-mail: nagamine.mitsue@ila.titech.ac.jp

${ }^{1} \mathrm{MN}$ has received a research grant from Pigeon Corporation. This work was supported by Grant-in-Aid for Scientific Research (C) (17K04459).

${ }^{2}$ We thank the Cortisol Laboratory, Department of Psychobiology, University of Trier, Germany, for performing the cortisol assay. We also thank all women who participated in this study during their pregnancy. 
【要 約】 妊娠期のストレスが胎児の発達に及ぼす影響に関するメカニズム解明および妊婦のストレス評価の重 要性が指摘されている。そのメカニズム解明においては, 内分泌系のストレス反応であるコルチゾール分泌変化 によるストレス評価が多く行われているが, 妊婦の精神健康とコルチゾールプロフィールおよび出産週数と出生 体重との関連性については，一貫した結果が得られていない。

本研究では, 44名 (中期20名, 後期 24名; 平均年齢29.3歳) の健康な妊婦を対象として, 唾液中コルチゾール 值 (起床後 1 時間の 4 ポイント (直後, $+30,+45,+60$ 分), および日内変化 4 ポイント $(8$ 時, 11 時, 15 時, 20 時)）と, GHQ 精神健康調査票 12 項目版 (GHQ-12) の得点により妊娠期の心理生物学的ストレス反応を評価し, 出産時週数㧍よび出生体重との関連を検討した。

階層線形モデルを用いてコルチゾール日内変化の潜在成長曲線分析を行ったところ, コルチゾールの切片と負の 傾きが有意であった。さらに，コルチゾール日内変化の切片拉よび線形の傾きが出生時週数および出生体重に及 ぼす影響を重回帰分析で検討したところ，線形の傾きが出生体重を有意傾向レベルで予測することが明らかとな った $(\beta=-.52, p<.10)$ 。これにより, 日内のコルチゾール分泌変化が平坦化しているほど, 出生体重が低いこ とが示され，コルチゾール分泌変化と精神健康における問題との関連性を検討する上で, 日内分泌リズムが重要 な指標となりうることが示唆された。

\section{Introduction}

Pregnancy typically leads to dramatic life changes. It is characterized not only by feelings of happiness but also maternal stress, anxiety, and depression. In fact, antenatal depression is comparable to nonpuerperal depression, and rates of antenatal depression, especially during the second and third trimesters of pregnancy, have been found to be substantial (Bennett et al., 2004).

Excessive maternal stress during pregnancy may adversely affect not just the mother but also the fetus (Jones et al., 2006). A significant number of reviews of maternal stress and fetal or child development indicates the importance of assessing the extent of maternal stress, as chronic stress during pregnancy is associated with adverse health outcomes for the offspring (Lewis et al., 2016; Wadhwa, 2005). Additionally, a substantial body of epidemiological and clinical evidence shows that psychosocial stress is significantly associated with shortened gestation and increased preterm birth (Dole et al., 2003; Dayan et al., 2006). Preterm infants are at high risk for serious health complications (Hasegawa et al., 2016); therefore, it is of utmost importance to detect and alleviate chronic stress during pregnancy.
One of the most salient mechanisms that underlie the relation between maternal stress and fetal development is cortisol dysregulation (Entringer et al., 2011; Lewis et al., 2016). Maternal cortisol acts on the developing fetus either directly through the placenta, or indirectly via its effects on placental production of the corticotropin-releasing hormone (Wadhwa, 2005). In addition, maternal cortisol levels and the length of gestation have been found to be negatively correlated with each other (Giurgescu, 2009). However, majority of studies (as much as $60 \%$ ) that reported a negative correlation between these two factors did so on the basis of limited data, that is, these studies were based on data collected only once during pregnancy (Giurgescu, 2009). Therefore, these studies do not provide an adequate account of the role of cortisol as a physiological measure of stress (Harville et al., 2007). Harville et al. (2007) have suggested that data could be collected multiple times in a single day, or twice every day for a certain period to overcome this shortcoming.

Prominent cortisol profiles related to health parameters include cortisol awakening response (CAR) and diurnal cortisol slope (DCS) (Adam \& Kumari, 2009). CAR, which refers to the marked increase in cortisol secretion over the first $30-45 \mathrm{~min}$ 
after morning awakening, has been found to be related to a wide range of psychosocial, physical, and mental health parameters. CAR, therefore, is a key variable in psychoneuro-endocrinological research (Stalder et al., 2015). Both heightened and blunted CARs have been found to be related to psychosocial stress and poor health outcomes (Adam \& Kumari, 2009). For DCS, the typical diurnal cortisol rhythm is characterized by high levels upon waking, with a steep morning rise followed by a steeper decline throughout the rest of the day (Kirschbaum \& Hellhammer, 1989). This is regarded as a healthy pattern (Adam \& Kumari, 2009), and deviations from the typical diurnal rhythm, such as flattening of the diurnal patterns, have been linked to poorer health outcomes (Dmitrieva et al., 2013; Karlamangla et al., 2013). Poorer health outcomes are known to be associated with altered hypothalamus-pituitary-adrenal (HPA) axis function in non-pregnant individuals, and in their 2010 meta-analysis, Knorr et al. (2010) reported that depressed adults displayed a small but significantly higher increase in morning and evening cortisol values than non-depressed adults. However, these findings may not be applicable to pregnant women, as pregnancy-related changes in HPA are wide-ranging and substantial (O'Connor et al., 2014). Several studies of pregnancy (O'Connor et al., 2014; Suglia et al., 2010) have found an association between depression or high stress and cortisol profiles, such as decreased morning levels and diminished diurnal decline.

A few studies have examined the relation between cortisol profiles (CAR or DCS) and infant outcomes (gestation period or birth weight) by collecting multiple samples from pregnant participants (Bolten et al., 2011; Buss et al., 2009; D'Anna-Hernandez et al., 2012; Entringer et al., 2011). The findings of these studies, however, were inconsistent. Some studies reported lacking or significant associations of maternal cortisol profiles and infant outcomes. For the length of gestation, some studies found that the significant association with CAR (Buss et al., 2009; Entringer et al., 2011), DCS (Entringer et al., 2011), but not in
D’Anna-Hernandez et al. (2012) study. Buss et al. (2009) found that a (i) higher CAR during late pregnancy and a (ii) reduced attenuation of CAR from early to late gestation were significantly associated with shorter gestational length. Entringer et al. (2011) assessed CAR and additional three points (at 12:00, 16:00, and 20:00, representing the short diurnal profile); they found that (i) higher salivary cortisol concentrations during awakening and throughout the rest of the day and (ii) a flatter cortisol response to awakening were associated with shorter gestation. D'Anna-Hernandez et al. (2012) found that there was no significant correlation between gestational age at birth and maternal diurnal slope cortisol throughout pregnancy. On the other hand, for birth weight, Bolten et al. (2011) found that the significant association with CAR and D'Anna-Hernandez et al. (2012) showed that the significant association with DCS. Bolten et al. (2011) found a negative association between CAR (area under the curve of cortisol awakening response) and birth weight, that is, newborns of mothers with higher cortisol levels during pregnancy had lower birth weight. D'Anna-Hernandez et al. (2012) showed that blunted cortisol slope was correlated with lower birth weight only during late pregnancy. This finding suggests that the association changes during stage of pregnancy.

Although CAR and DCS may indicate a long-term response to chronic stress, the associations between these cortisol profiles, mental health, gestation period, and birth weight have not been examined concurrently. This study, therefore, aims to examine the relationship between cortisol profiles (CAR and DCS), mental health, gestation period, and infant birth weight during the second and third trimesters of pregnancy to identify the factor that most accurately predicts fetal growth.

\section{Methods}

Participants. All participants were healthy, pregnant women registered for monitoring at the Research \& Development Division, Pigeon Corporation, Ibaraki, 
Japan. In total, we approached 48 potential participants $(N=48)$; however, four participants could not complete the study (fetal death $[n=1]$, no birth data received $[n=3])$. The final sample, therefore, consisted of 44 participants.

Participants were aged between 19 and 39 years (mean age: $29.3 \pm 3.7$ years), and their gestational ages ranged between 19 and 39 weeks. Of these, 20 women belonged to the mid-term pregnancy group (mean gestational age $22.8 \pm 3.5$ weeks), and 24 women belonged to the late-term pregnancy group (mean gestational age $35.2 \pm 2.9$ weeks). All participants were married, and there were no significant between-group differences in the number of primipara. Women in the late-term group had significantly more years of education than women in the mid-term group $(13.2 \pm 2.6$ versus $11.6 \pm 1.8$ years, respectively) $(t(41)=2.4, p<.05)$. None of the participants had any active psychiatric disorders or other medical illnesses. We contacted participants after delivery to collect infant information, such as the exact length of gestation and infant birth weight.

All participants received monetary compensation (JPY 3000) for their participation. This study was approved by the Institutional Ethics Committee of the Pigeon Corporation, Ibaraki, Japan, and written informed consent was obtained from all participants.

Procedures. Pregnant women were required to collect saliva samples for cortisol assays at $0,30,45$, and $60 \mathrm{~min}$ after awakening (representing CAR), and at 8:00 11:00, 15:00, and 20:00 (representing DCS) over the course of a day. The subjects were instructed to refrain from eating and drinking during the first hour after awakening. After each time saliva was collected, the swabs were stored in a plastic tube labeled with the designated sampling time. Participants received a batch of saliva sampling devices (Salivette; Sarstedt, Germany) to assess their cortisol levels throughout the selected day. We demonstrated the correct method for using the Salivettes, and the participants practiced collecting saliva at their homes. They were instructed to refrain from brushing their teeth and eating at least 30 min prior to the sampling. They were also instructed to provide saliva samples on an ordinary day, that is, not on a special day, and to refrigerate the samples until they were collected by a researcher. Participants were also provided a diary, in which they were requested to record the time of awakening, time of sleeping, quality of sleep, and sleep satisfaction (scored on a scale of 1 [very bad] to 6 [very good]). It also included the Japanese version of the General Health Questionnaire (GHQ-12) (Fukunishi, 1990) for mental health assessment.

Cortisol assay. The collected samples were stored at $-20^{\circ} \mathrm{C}$ in the laboratory until further use.

Saliva samples were assayed at the Cortisol Laboratory of Trier University (Trier, Germany). Salivettes were centrifuged at $2,000 \times g$ for $10 \mathrm{~min}$ to obtain a clear supernatant of low viscosity. Cortisol levels were determined using a competitive solid phase time-resolved fluorescence immunoassay with fluorometric end-point detection (DELFIA). The intra-assay coefficients of variation were between $4.0 \%$ and $6.7 \%$, and the corresponding inter-assay coefficients of variation were between $7.1 \%$ and $9.0 \%$ (Dressendörfer et al., 1992).

Data analysis. The area under the curve (AUCg) of the cortisol awakening response (AUCg_CAR: 0, 30,45 , and $60 \mathrm{~min}$ after awakening) and during-theday (AUCg_day: 8:00, 11:00, 15:00, and 20:00) samples were calculated using the trapezoid method with respect to ground (Pruessner et al., 2003).

The slope of diurnal change in the cortisol level was calculated to estimate how each participant fit the normal profile (i.e., high in the morning and low in the evening).

Participants were classified into non-distressed (ND) and distressed (D) groups based on their GHQ scores (using 0-0-1-1 scoring) (scores of 0-2 were $\mathrm{ND}$, scores of $\geq 3$ were $\mathrm{D}$ ).

Repeated analyses of variance (ANOVA) measures with pregnant stage and group (ND or D) as class variables and cortisol profiles (CAR: $0 \mathrm{~min}, 30 \mathrm{~min}$, $45 \mathrm{~min}, 60 \mathrm{~min}$; diurnal rhythm: 8:00, 11:00, 15:00, 
20:00) as a repeated measure were conducted to examine simple effects and, when appropriate, Bonferroni tests were conducted on all significant findings.

Intercept and linear and quadratic slopes of diurnal cortisol change were examined by latent growth curve analysis using Hierarchical Linear Modeling (HLM). Following this, we examined the effects of these intercepts and slopes of diurnal cortisol change on gestation period and birth weight among newborns through multiple regression.

We adjusted the degrees of freedom on the basis of the sphericity assumption. To this end, we employed the Greenhouse-Geisser approach, whenever applicable. An alpha level of .05 was used for all statistical tests. The data were analyzed with SPSS for Windows statistical software package (version 22.0; SPSS, Chicago, IL, USA) and HLM for Windows (version 6.08; Scientific Software International, Lincolnwood, IL, USA).

\section{Results}

\section{Mental health status and sleep data}

The number of women in late-term pregnancy who were stressed was found to be higher than the number of women who were stressed in mid-term pregnancy although the difference was not significant $(54 \%[n=$ 13] in late-term, $35 \%[n=7]$ in mid-term: $\chi^{2}(1)=$ $0.20, p=.24)$.
As shown in Table 1, sleeping time was shortened in late-term pregnancy. Analyses of variance (pregnant stage by group) revealed that pregnancy state had a significant main effect on sleeping time $(F(1,40)=6.29, p<.05)$.

\section{Cortisol profiles}

For CAR, analysis of variance (pregnant stage by group) for repeated measures revealed only the significant main effect of time after awakening $(F(3,114)=11.41, p<.001, \varepsilon=.66)$. Cortisol increased significantly from 0 to $30 \mathrm{~min}$ and decreased significantly from 30 to $60 \mathrm{~min}(p<.001, p<.01$, respectively) (Figure 1).

For DCS, analysis of variance (pregnant stage by group) for repeated measures revealed significant diurnal rhythm by group effect $(F(3,117)=10.69$, $p<.001, \varepsilon=.67)$. Simple main effect revealed that the significant cortisol decrease from 8:00 was first shown at 15:00 in D group $(p<.001)$, whereas in ND group, the significant decrease was shown earlier, at 11:00 $(p<.001)$. Additionally, cortisol levels were significantly higher at 8:00 but lower at 11:00 $(p<.05)$ in ND group compared with D group (Figure 2).

For AUCg_CAR and AUCg_day, analyses of variance (pregnant stage by group) revealed only the significant main effect of the stage of pregnancy $(F(3,39)=6.35, p<.05)$ on AUCg_day. AUCg_day was higher in late-term pregnancy than in mid-term pregnancy (Table 2).

Table 1. Sleep data obtained from the four groups of pregnant women.

\begin{tabular}{|c|c|c|c|c|}
\hline & \multicolumn{2}{|c|}{ Mid-term } & \multicolumn{2}{|c|}{ Late-term } \\
\hline & $\begin{array}{l}\text { Non-distressed } \\
\quad(n=13)\end{array}$ & $\begin{array}{l}\text { Distressed } \\
\quad(n=7)\end{array}$ & $\begin{array}{l}\text { Non-distressed } \\
\quad(n=11)\end{array}$ & $\begin{array}{l}\text { Distressed } \\
\quad(n=13)\end{array}$ \\
\hline Awakening time & $6: 26(0: 41)$ & $6: 41(0: 44)$ & $6: 48(0: 35)$ & $6: 21(0: 46)$ \\
\hline Sleeping time $(\min )$ & $405.5(54.7)$ & $432.1(55.7)$ & $386.8(53.8)$ & $366.2(53.5)$ \\
\hline Quality of sleep $(1-6)^{a}$ & $3.8(0.8)$ & $4.0(0.8)$ & $3.9(0.9)$ & $3.4(0.9)$ \\
\hline Satisfaction of sleep $(1-6)^{b}$ & $3.8(1.0)$ & $4.0(1.0)$ & $3.9(0.9)$ & $3.3(1.1)$ \\
\hline
\end{tabular}

Values are presented as Mean $(S D)$.

a Quality of sleep: “How would you rate last night's sleep?” (1 [very bad] to 6 [very good])

${ }^{\mathrm{b}}$ Sleep satisfaction: “To what extent were you satisfied with last night's sleep?” (1 [very bad] to 6 [very good]). 


\section{Association between GHO score, DCS and} gestation period, or birth weight

As mentioned above, only DCS showed significant group difference, therefore DCS was examined by latent growth curve analysis using HLM. The result showed that the intercept, linear slope and quadratic slope were significant $(b=15.15,-1.79, .074$, $p \mathrm{~s}<.001)$. For random effects, all the variabilities of intercept and linear and quadratic slopes were found
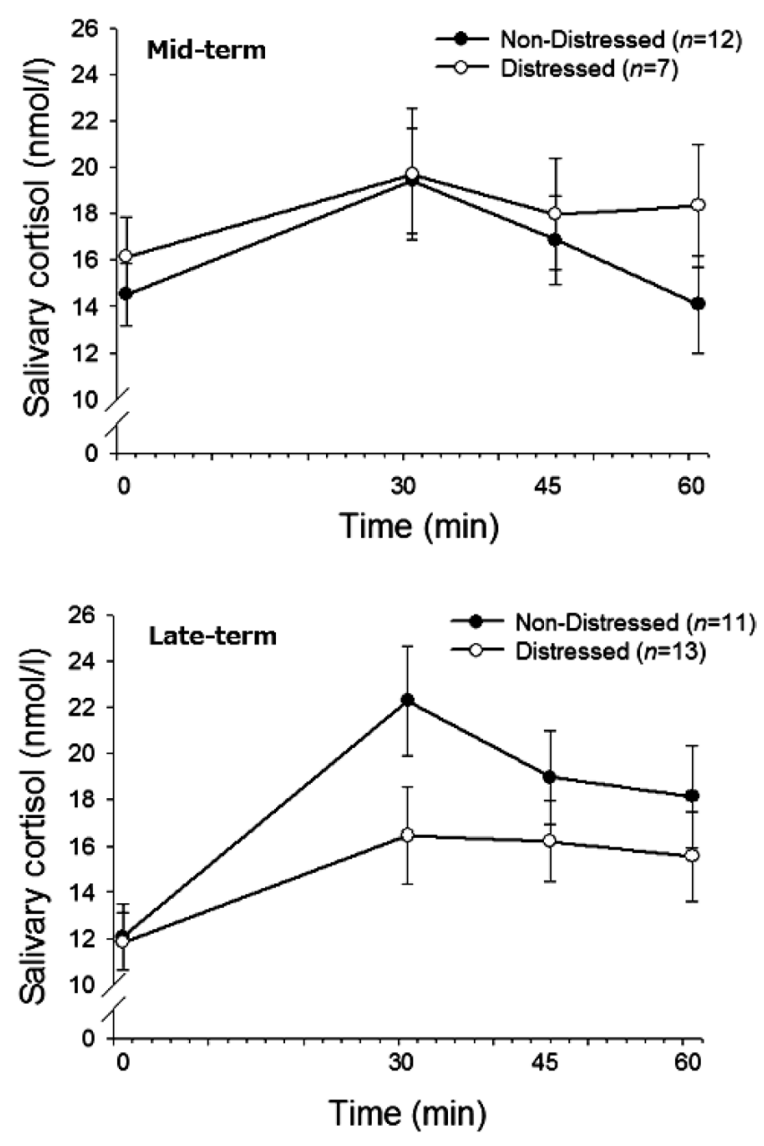

Figure 1. Cortisol awakening response in two groups of mid-term or late-term pregnancy. to be significant $(S D=4.84, p<.001 ; S D=1.15$, $p<.001 ; S D=.07, p<.05$, respectively).

For step1, we entered factors such as maternal age, pre-pregnancy BMI, infant's sex, stage of pregnancy, time from awakening to 8:00 ( $\mathrm{min}$ ); at step2, we entered the GHQ scores. At step3, we entered the intercept and linear slope of diurnal cortisol change as predictors into the regression equation of infant's birth weight and gestation period. The quadratic slope was

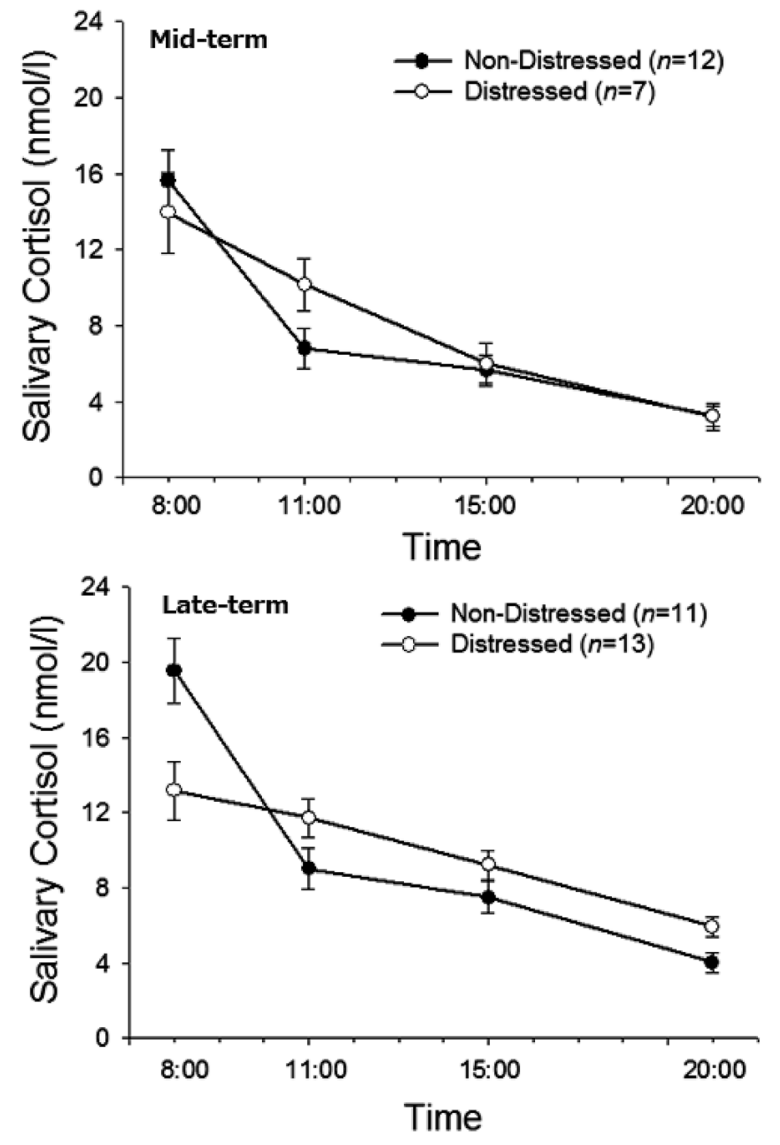

Figure 2. Cortisol diurnal rhythm in two groups of mid-term or late-term pregnancy.

Table 2. Cortisol AUCg profiles in the four groups of pregnant women.

\begin{tabular}{lccccc}
\hline & \multicolumn{2}{c}{ Mid-term } & & \multicolumn{2}{c}{ Late-term } \\
\cline { 2 - 3 } \cline { 5 - 6 } & $\begin{array}{c}\text { Non-distressed } \\
(n=12)\end{array}$ & $\begin{array}{c}\text { Distressed } \\
(n=7)\end{array}$ & & $\begin{array}{c}\text { Non-distressed } \\
(n=11)^{\mathrm{a}}\end{array}$ & $\begin{array}{c}\text { Distressed } \\
(n=13)\end{array}$ \\
\hline AUCg_CAR & $1009.1(256.1)$ & $1093.3(368.2)$ & & $1103.7(342.1)$ & $907.8(295.1)$ \\
AUCg_day & $4838.9(1821.7)$ & $5483.3(2728.9)$ & & $6271.4(1538.8)$ & $7020.2(1646.1)$ \\
\hline
\end{tabular}

Values are presented as Mean $(S D)$.

${ }^{a}$ Number of participants were 10 for AUCg_CAR.

AUCg: area under the curve, CAR: cortisol awakening response 
Table 3. Multiple linear regression predicting gestation period and birth weight with the relevant predictors $(N=43)^{\mathrm{a}}$.

\begin{tabular}{|c|c|c|c|c|}
\hline \multirow{2}{*}{ Variables } & \multicolumn{2}{|c|}{ Gestation period } & \multicolumn{2}{|c|}{ Birth weight } \\
\hline & $\beta$ & $p$ & $\beta$ & $p$ \\
\hline \multicolumn{5}{|l|}{ Step 1 (Covariates) } \\
\hline Maternal age & -.16 & .37 & -.19 & .19 \\
\hline Pre-pregnancy BMI & .09 & .51 & .46 & $<.01$ \\
\hline Infant's sex $($ female $=0)$ & -.00 & .98 & .11 & .42 \\
\hline Pregnant Stage $($ mid-term $=0)$ & .03 & .89 & .13 & .39 \\
\hline Time from awakening time to $8: 00(\mathrm{~min})$ & .12 & .54 & .35 & .03 \\
\hline \multicolumn{5}{|l|}{ Step 2: Predictor } \\
\hline GHQ scores & .06 & .77 & .10 & .52 \\
\hline \multicolumn{5}{|l|}{ Step 3: Predictor } \\
\hline Cortisol diurnal intercept & -.08 & .83 & -.41 & .15 \\
\hline Cortisol diurnal slope & -.17 & .65 & -.52 & .09 \\
\hline Adjusted $R^{2}$ & -.17 & & .27 & \\
\hline$F_{\text {Model }}$ & $F(8,34)=0.23$ & .98 & $F(8,34)=2.96$ & .01 \\
\hline
\end{tabular}

BMI: body mass index

${ }^{\text {a }}$ Number of participants were 43 because of one missing value for pre-pregnancy BMI.

not entered as a predictor into the equation because it had a high correlation with the linear slope $(r=-.99)$.

Table 3 shows the results of the multiple regression analysis: cortisol diurnal slope was found to be negatively associated with infant's birth weight $(\beta=$ $-.52, p=.09)$, after controlling for maternal age, prepregnancy BMI, infant's sex, stage of pregnancy, and 8:00 min from awakening time.

\section{Discussion}

The main finding of this study is that cortisol diurnal slope may be a better indicator of mental health status than CAR; it may also be a better predictor of infant's birth weight. We first compared the association between CAR, DCS, and mental health state assessed by GHQ-12; we found that DCS clearly differentiated between D and ND groups. D group had a flatter cortisol diurnal rhythm than ND group. These results support the findings reported by several previous studies, which showed a flattening of the diurnal patterns. The flattening was characterized by lower morning levels and a flatter diurnal decline, which in turn were linked to poorer mental health outcomes during pregnancy (Dmitrieva et al., 2013; Karlamangla et al., 2013). GHQ is an assessment tool designed to evaluate mental health state over a period, typically over several weeks; therefore, it reflects chronic, not acute, stress. The results of the present study also indicate an association between chronic stress and a flatter diurnal cortisol rhythm.

The results also strengthen the findings of O'Connor et al. (2014), who found a modest, but significant, association between depression and a flattened, less sharply declining diurnal pattern. Their study sampled women at high psychosocial risk, i.e., low level of educational attainment (26\% had not completed high school), high percentage of single parents (71\%), and comparatively high incidence of disorders (diagnoses for depression and anxiety were $23 \%$ and $24 \%$, respectively). On the other hand, the present study sampled relatively low-risk individuals, i.e., only $14 \%$ did not complete high school and none were single parents; the findings are comparable nonetheless. 
Interestingly, although there was a significant association between mental health and cortisol diurnal rhythm, multiple regression analysis showed no significant association between GHQ score and birth weight. This result can be interpreted in two ways: (i) the instrument used in this study to assess mental health does not adequately explain offspring development or (ii) biological stress response, such as cortisol dysregulation, has a more prominent impact on offspring development. As for the first point, reports on the association between prenatal stress and cortisol levels in human pregnancy were conflicting; a previous study (Bolten et al., 2011) has also argued similarly. Some studies report a significant relation between prenatal stress and cortisol levels, whereas some studies found no such relation. In this study, GHQ was used to assess maternal stress, and we found a significant association between GHQ scores and cortisol diurnal slope. GHQ has been extensively used in different settings (Montazeri et al., 2003), including pregnancy (Nast et al., 2013). It was developed mainly for the general population; therefore, it is not the best tool for measuring pregnancy-specific stress. Moreover, it may also underestimate the level of stress during pregnancy (DiPietro et al., 2004). As for the second point, Zijlmans et al. (2015) report that the significant association between maternal prenatal cortisol and child outcomes is small, which suggests that maternal cortisol may not be the sole underlying mechanism to understand the relation between these variables. Further research is necessary to identify and evaluate additional biological indexes to understand the complex pathway from maternal bio-psycho-social stress to offspring development.

We did not find a significant association between CAR and mental health state. This may be due to the sampling method. A previous study conducted by Bolten et al. (2011) reported significant negative associations between CAR (area under the curve) and birth weight. In their study, saliva samples were collected on two workdays. In addition, studies have also reported weekend and weekday differences in CAR (Schlotz et al., 2004; Thorn et al., 2006). In the present study, however, the sampling day was not selected by the researcher; the participants chose the day from within one week. Therefore, the data for CAR in this study included weekdays and weekends, which may make it difficult to find associations between CAR and mental health state. The results may not show that CAR is not associated with mental health state; rather, it may suggest that DCS is a more robust measure of chronic stress than CAR. Further research is needed to more accurately explain the method used to assess pregnancy-related stress; this may also reduce, if not eliminate, the need for multiple sampling.

This study has the following limitations. First, the sample size is rather small, resulting in limited statistical power. Furthermore, this study was crosssectional in design; therefore, we were unable to examine how patterns of cortisol secretion throughout pregnancy may be related to fetal growth. Further longitudinal investigation is needed to identify the gestational age most sensitive to prenatal stress. While evidence increasingly suggests that prenatal stress and postnatal developmental outcomes may be associated, there is currently little agreement about the gestational age most sensitive to such stress (Talge et al., 2007).

For women in developed countries, the average age at childbirth has been increasing in the past few decades. This is mainly due to social, educational, and economic factors (Walker et al., 2016). For instance, in 2016, Japanese women aged 35 years or older accounted for $28 \%$ of births in the country (Ministry of Health, Labour, and Welfare, 2017). There is a higher risk of adverse pregnancy outcomes, including preterm birth and low birth weight, in older women (Walker et al., 2016); therefore, to promote safe pregnancy and delivery, it is important to facilitate the development of supportive health policies and a community healthcare system for younger, as well as older mothers. To this end, it is necessary to identify more biological markers. 
In sum, we report that cortisol diurnal rhythm is more sensitive than CAR in predicting the fetal birth weight.

\section{References}

Adam, E. K., \& Kumari, M. (2009). Assessing salivary cortisol in large-scale, epidemiological research. Psychoneuroendocrinology, 34, 14231436.

Bennett, H. A., Einarson, A., Taddio, A., Koren, G., \& Einarson, T. R. (2004). Prevalence of depression during pregnancy: Systematic review. Obstetrics \& Gynecology, 103, 698-709.

Bolten, M. I., Wurmser, H., Buske-Kirschbaum, A., Papousek, M., Pirke, K. M., \& Hellhammer, D. (2011). Cortisol levels in pregnancy as a psychobiological predictor for birth weight. Archives of Women's Mental Health, 14, 33-41.

Buss, C., Entringer, S., Reyes, J. F., Chicz-DeMet, A., Sandman, C. A., Waffarn, F., \& Wadhwa, P. D. (2009). The maternal cortisol awakening response in human pregnancy is associated with the length of gestation. American Journal of Obstetrics Gynecology, 201, 398 e391-398.

D’Anna-Hernandez, K. L., Hoffman, M. C., Zerbe, G. O., Coussons-Read, M., Ross, R. G., \& Laudenslager, M. L. (2012). Acculturation, maternal cortisol, and birth outcomes in women of Mexican descent. Psychosomatic Medicine, 74, 296-304.

Dayan, J., Creveuil, C., Marks, M. N., Conroy, S., Herlicoviez, M., Dreyfus, M., \& Tordjman, S. (2006). Prenatal depression, prenatal anxiety, and spontaneous preterm birth: A prospective cohort study among women with early and regular care. Psychosomatic Medicine, 68, 938-946.

DiPietro, J. A., Ghera, M. M., Costigan, K., \& Hawkins, M. (2004). Measuring the ups and downs of pregnancy stress. Journal of Psychosomatic Obstetrics \& Gynecology, 25, 189-201.

Dmitrieva, N. O., Almeida, D. M., Dmitrieva, J., Loken, E., \& Pieper, C. F. (2013). A day-centered approach to modeling cortisol: Diurnal cortisol profiles and their associations among U.S. adults. Psychoneuroendocrinology, 38, 2354-2365.

Dole, N., Savitz, D. A., Hertz-Picciotto, I., Siega-Riz, A. M., McMahon, M. J., \& Buekens, P. (2003). Maternal stress and preterm birth. American Journal of Epidemiology, 157, 14-24.

Dressendörfer, R. A., Kirschbaum, C., Rohde, W., Stahl, F., \& Strasburger, C. J. (1992). Synthesis of a cortisol-biotin conjugate and evaluation as a tracer in an immunoassay for salivary cortisol measurement. Journal of Steroid Biochemistry and Molecular Biology, 43, 683-692.

Entringer, S., Buss, C., Andersen, J., Chicz-Demet, A., \& Wadhwa, P. D. (2011). Ecological momentary assessment of maternal cortisol profiles over a multiple-day period predicts the length of human gestation. Psychosomatic Medicine, 73, 469-474.

Fukunishi, I. (1990). The assessment of cut-off point of the General Health Questionnaire (GHQ) in the Japanese version. Journal of Japanese Clinical Psychology, 3, 228-234.

Giurgescu, C. (2009) . Are maternal cortisol levels related to preterm birth? Journal of Obstetric, Gynecologic, \& Neonatal Nursing, 38, 377-390.

Harville, E. W., Savitz, D. A., Dole, N., Herring, A. H., Thorp, J. M., \& Light, K. C. (2007). Patterns of salivary cortisol secretion in pregnancy and implications for assessment protocols. Biological Psychology, 74, 85-91.

Hasegawa, J., Toyokawa, S., Ikenoue, T., Asano, Y., Satoh, S., Ikeda, T., ... Ueda, S. (2016). Relevant obstetric factors for cerebral palsy: From the nationwide obstetric compensation system in Japan. PLoS One, 11, e0148122. doi:10.1371/journal. pone. 0148122

Jones, N. M., Holzman, C. B., Zanella, A. J., Leece, C. M., \& Rahbar, M. H. (2006). Assessing mid-trimester salivary cortisol levels across three consecutive days in pregnant women using an athome collection protocol. Paediatric and Perinatal Epidemiology, 20, 425-437. 
Karlamangla, A. S., Friedman, E. M., Seeman, T. E., Stawksi, R. S., \& Almeida, D. M. (2013). Daytime trajectories of cortisol: Demographic and socioeconomic differences-Findings from the national study of daily experiences. Psychoneuroendocrinology, 38, 2585-2597.

Kirschbaum, C., \& Hellhammer, D. H. (1989). Salivary cortisol in psychobiological research: An overview. Neuropsychobiology, 22, 150-169.

Knorr, U., Vinberg, M., Kessing, L. V., \& Wetterslev, J. (2010). Salivary cortisol in depressed patients versus control persons: A systematic review and meta-analysis. Psychoneuroendocrinology, 35, $1275-1286$.

Lewis, A. J., Austin, E., \& Galbally, M. (2016). Prenatal maternal mental health and fetal growth restriction: A systematic review. Journal of Developmental Origins of Health and Disease, 7, 416428.

Ministry of Health, Labour, and Welfare. (2017). Vital statistics of Japan, 2016. Statistics and Information Department, Tokyo, Japan.

Montazeri, A., Harirchi, A. M., Shariati, M., Garmaroudi, G., Ebadi, M., \& Fateh, A. (2003). The 12item General Health Questionnaire (GHQ-12): Translation and validation study of the Iranian version. Health and Quality of Life Outcomes, 1, 66.

Nast, I., Bolten, M., Meinlschmidt, G., \& Hellhammer, D. H. (2013). How to measure prenatal stress? A systematic review of psychometric instruments to assess psychosocial stress during pregnancy. Paediatric and Perinatal Epidemiology, 27, 313-322.

O’Connor, T. G., Tang, W., Gilchrist, M. A., Moynihan, J. A., Pressman, E. K., \& Blackmore, E. R. (2014). Diurnal cortisol patterns and psychiatric symptoms in pregnancy: Short-term longitudinal study. Biological Psychology, 96, 35-41.

Pruessner, J. C., Kirschbaum, C., Meinlschmid, G., \& Hellhammer, D. H. (2003). Two formulas for computation of the area under the curve represent measures of total hormone concentration versus time-dependent change. Psychoneuroendocrinology, 28, 916-931.

Schlotz, W., Hellhammer, J., Schulz, P., \& Stone, A. A. (2004). Perceived work overload and chronic worrying predict weekend-weekday differences in the cortisol awakening response. Psychosomatic Medicine, 66, 207-214.

Stalder, T., Kirschbaum, C., Kudielka, B. M., Adam, E. K., Pruessner, J. C., Wüst, S., ... Clow, A. (2015) . Assessment of the cortisol awakening response: Expert consensus guidelines. Psychoneuroendocrinology, 63, 414-432.

Suglia, S., Staudenmayer, J., Cohen, S., Enlow, M., Rich-Edwards, J., \& Wright, R. (2010). Cumulative stress and cortisol disruption among Black and Hispanic pregnant women in an urban cohort. Psychological Trauma: Theory, Research, Practice, and Policy, 2, 326-334.

Talge, N. M., Neal, C., \& Glover, V. (2007). Antenatal maternal stress and long-term effects on child neurodevelopment: How and why? Journal of Child Psychology and Psychiatry, 48, 245-261.

Thorn, L., Hucklebridge, F., Evans, P., \& Clow, A. (2006). Suspected non-adherence and weekend versus week day differences in the awakening cortisol response. Psychoneuroendocrinology, 31, 1009-1018.

Wadhwa, P. D. (2005). Behavioral Perinatology. In A. Riecher-Roessler \& M. Steiner (Eds.), Perinatal stress, mood and anxiety disorders. From bench to bedside (pp. 50-69). Basel: Karger.

Walker, K. F., Bugg, G. J., Macpherson, M., McCormick, C., Grace, N., Wildsmith, C., ...Thornton, J. G. (2016). Randomized trial of labor induction in women 35 years of age or older. The New England Journal of Medicine, 374, 813-822.

Zijlmans, M. A., Riksen-Walraven, J. M., \& de Weerth, C. (2015). Associations between maternal prenatal cortisol concentrations and child outcomes: A systematic review. Neuroscience \& Biobehavioral Reviews, 53, 1-24. 